\title{
"Patenting" a New Engineering Librarian at an American University in the UAE
}

\section{Mrs. Amani Magid, New York University Abu Dhabi}

Amani Magid has a degree in Integrative Biology and a minor in Arabic from University of California, Berkeley. In her career as a scientist, she has worked as a researcher in Pharmaceutical Chemistry and managed biology lab classes at a community college. She soon realized her passion was in finding and locating science information and earned her Masters in Library and Information Science at University of Pittsburgh while interning at Bayer Material Science Library. She worked in Qatar for over five years as a Medical Librarian before her present position as a Science and Engineering Librarian at New York University Abu Dhabi. 


\title{
"Patenting" a New Engineering Librarian at an American University in the UAE
}

\begin{abstract}
As an engineering librarian, my first instruction session consisted of teaching students about patents and how to search the patent literature. I learned a great deal about patents and what can and cannot be patented. Of course, a person cannot be patented, let alone a profession. The question still remains as to what if it was a possibility and what would that patent look like? As a librarian who liaised with the science community exclusively for a year before taking on engineering, I have learned from point zero. I have no background in engineering and my previous library career path did not include any engineering liaison assignments. In the same matter that some patents begins with an idea and that idea then becomes a product, I started with the idea of an "engineering librarian" and made that idea a reality. Through interacting with the faculty, attending lectures, attending training sessions, and communicating with my counterparts in the US, both in-person and online, I have learned and continue to learn about engineering librarianship, particularly at my institution. Like a patent, this paper will take one through all the claims and diagrams that consist of my path in learning the skills required to become an engineering librarian at an American University in the UAE.
\end{abstract}

\section{Introduction}

Many academic librarians who liaise with a specific subject area(s), are aware that a certain amount of knowledge about the subject area will help immensely when aiding students and professors with their information needs. My own personal experience has shown that with my background in biology, I can easily help scientists with library related queries, as I am familiar with the terminology. In my first library job, I worked at a medical library in which I was required to take a short course in medical terminology to better help the patrons with their queries. This short course helped me immensely as I worked in medical libraries for an additional six years at two different locations. Of course, my undergraduate degree in Biology also helped as well, but it was the Medical terminology course that helped in assisting the physicians. When I made the transition from a medical librarian to a science librarian over two years ago, I still felt that the medical terminology and biology background made a difference in my approach to library queries in that they were familiar to me. However, when I also started to liaise with the engineering department on campus, I did not have any background in engineering, other than that I knew that engineers build buildings and roads and create gadgets and devices that we use today. So I knew I needed to educate myself on engineering in order to better help the students and faculty with using library resources. I approached this challenge with a variety of tools and strategies that is proving to be fruitful.

New York University Abu Dhabi (NYUAD), located in Abu Dhabi in the United Arab Emirates, was established in 2010 and has since graduated two classes. A portal campus of New York University (NYU) in New York, USA it is primarily an undergraduate liberal arts college with a total student population of about 880 . Students may choose one or more of 22 different areas of study to focus on including Arts and Humanities, Social Research and Public Policy, History, Economics, Sciences, and Engineering. Within Engineering, students can decide to have a focus in either civil, computer, electrical, general, or mechanical engineering ${ }^{1}$. 
As mentioned in the abstract, this paper is organized as if it were a patent, containing claims and subclaims. As the paper will describe "patenting" an engineering librarian at an American university, the patent will follow the patents issued by the United States Patent and Trademark Office (USPTO). The three types of patents issued by the USPTO are utility, design, and plant. The patent described for this paper is similar to a design patent, as an engineering librarian is not a new job title. More specifically, the paper is organized into claims that are essential components of patents issued by the United States. According to the USPTO, "The claim or claims shall define the matter for which protection is sought. Claims shall be clear and concise. They shall be fully supported by the description"2. Claims describe the patent and they are divided into two sections, the prior art and the description of what is sought to be protected ${ }^{2}$. Prior art is defined as all the publicly available information that your invention is not unknown ${ }^{3}$. It is similar to references in the literature in the library world. Therefore, under each claim there is "prior art", which for the purposes of this paper, is akin to a literature review. Under each claim there are "subclaims". Although subclaims do not exist in the USPTO literature, dependent claims do. Dependent claims "... refer back to and further limit another claim" 4 . Essentially, they will provide more detailed information for the claim. For the purposes of this paper, the subclaims will further detail the claims.

The paper is written in the form of a patent because in the author's transition from a medical librarian in a previous position to a Science and Engineering Librarian in her present position, nothing better distinguishes the three fields of librarianship than intellectual property and patents that dominate in engineering ${ }^{5}$. Although innovation and patents are a component of the medical and science fields, they do not necessarily lead to patents as much as in the engineering field. Of course, a person cannot be patented, but from this point on, the patenting in question is the author as a new engineering librarian.

Claim 1. In liaising with a new department, Engineering, make sure to reach out to the Engineering Department

In an academic setting, reaching out to faculty to determine the information needs of both them and their students is one of many aspects of a librarian's duties. An engineering librarian in a college/university setting is no different, whether the librarian works as part of a main library or in a separate engineering library. Nelson has developed an extensive marketing plan of the engineering library at Purdue University where outreach to faculty is one of many facets ${ }^{6}$. At Dalhousie University, Dooley recognizes that working with faculty can build "mutually beneficial outcomes" for both librarian and faculty that may lead to both parties seeing each other as equals in the university setting ${ }^{7}$.

Subclaim 1.1 Introduce yourself to the faculty who teach engineering students As a subject specialist librarian, there are certain things the author does at certain points of the semester. One of the constants tasks the author must complete at the end of each semester is to email every faculty teaching a class the next semester in the areas that she liaises to. The email is to make the faculty aware of the services the author can provide to their students while they are enrolled in their class. The author emphasizes that she can teach the students how to use library resources and services to help them complete assignments and research papers (See Subclaim 2). Most notably, she emphasizes that she can help them search the literature for books, journals and articles. So when the author became the liaison to Engineering, she did just this and also introduced herself as the Science and Engineering Librarian. She received some responses from the faculty and met with them before teaching in the classes. Because she was new to the field, she asked the professors to provide examples 
of research topics that the students would need to search the literature. The author was also not shy about questioning the faculty of the subject matter so that she could have a clearer understanding of it. A better understanding contributes to devising more adequate keywords for searching the literature.

\section{Subclaim 1.2 Meet with the Dean of Engineering at your Institution}

The author also made it a priority to meet with the Dean of Engineering on campus. In order to make an appointment with the Dean she had to introduce herself to the Engineering Manager, who not only is versed in the Dean's calendar better than he is, but also oversees all the engineering assistants. Fortunately, both the Engineering Manager and the Dean are very personable, making the effort to network all the more enjoyable. The Dean of Engineering is the best dean the author has come to work with, in that he is a strong supporter of the library. He has approached the author many times about purchasing library resources related to engineering and has also been open to her attendance at engineering faculty meetings. Although, she could have attended every meeting, she chose to be selective and come with a goal for each of the meetings attended. For the first meeting, the author introduced herself to the entire faculty and made them aware of the library resources and services that are available (See Subclaim 1.1). For each meeting the author either talked about resources and services already in place or asked for their opinions on purchasing decisions. The meetings were undeniably worth the time and effort in communicating with the faculty and alerting them to the library's presence and willingness to become a supporter of engineering education and resources.

Subclaim 1.3 Embed yourself in the area in which your patrons work Before she added "engineering" to her job title, one of the author's services is Science Librarian Day, in which she visits the science/engineering building twice a month and spends the entire day there, by reserving an empty conference room or an office. She brings treats and answers questions on library related resources and services ${ }^{8}$. These have been well attended in that many of the faculty, staff, and postdoctoral scholars have reported to the author that they sometimes only have 5-10 minutes free when they are running experiments and they can quickly ask a question in person while she is there. When the author began to liaise to engineering, she changed the name of the service to Sci-Eng Librarian Day, to reflect the new patron base. Many engineering faculty, staff, and postdoctoral scholars stop by for questions and sometimes just to chat and to enjoy a treat as a break from work. Many times these informal chats turn into research questions and questions about library resources and services in subsequent visits. In addition the author is fond of chatting with people so the SciEng Librarian Days are not only productive in that she is finding out the needs of her patron base, but enjoyable days outside of the normal routine.

Claim 2. In liaising with a new department, Engineering, educate yourself on the subject matter

In acquiring a new liaison area, it is important to learn the subject matter. This helps immensely in communicating with faculty and helping both faculty and students with literature and other library requests. In addition, it can help in fostering future higher-level collaborations with faculty ${ }^{9,10}$. Knowing the language of your subject area and being able to "speak the language" add to a liaison librarians' relevance among faculty of that department

11 . In a survey of faculty at Texas A\&M University a little more than $50 \%$ of faculty ranked a librarians' background in the subject they are a liaison to as Very Important, on a scale of Very Important-Important-Not Important ${ }^{12}$. 
One relatively recent method of learning about a liaison subject matter is through creating a Twitter feed. Although there is an abundance of literature on the use of Twitter as an instructional tool for information literacy, there is not much on the use of Twitter for professional development of librarians in any field, let alone engineering librarianship. Dalton explains that there is some hesitancy to use Twitter for professional development, even among librarians who completed their library degree less than five years ago ${ }^{13}$. In an ethnographic study of a Texas school librarian Twitter chat group, the majority of respondents to a survey reported that they found the chat group useful in allowing them to learn about new technology and trends in their field ${ }^{14}$. Twitter can also be used to hold professional development events, such as with \#uklibchat, and to attend conferences and training events virtually, provided people attending those events are tweeting about it ${ }^{15}$.

Subclaim 2.1 Attend engineering lectures at your institution

Along the way of "patenting" a new engineering librarian, it was essential that the author learn the terminology of this new liaison area. Luckily, the engineering department hosts weekly talks in which professors from other universities will discuss different aspects of engineering research ${ }^{5}$. The author makes a point to attend as many of those talks as possible. Although there are many times in which certain terms in the talk are unfamiliar, bringing a mobile device allows for a quick and easy search of those terms. Noting new terms on a mobile device aids the author in decisions for collection development. On many occasions, materials have been purchased based on newly gained knowledge from attending these lectures. In addition, attending these lectures helps to strengthen ties with the faculty as the author's presence indicates, among other things, a vested interest in the subject matter (See Subclaim 1.2).

\section{Subclaim 2.2 Sign up for Engineering Listservs}

The author has discovered quite a few ways to learn online. In particular, signing up to engineering listservs has proved immensely helpful in expanding knowledge of engineering librarianship. Through daily and/or weekly emails from other librarians, she has learned about many issues that engineering librarians are dealing with from new patent tutorials to how to gain access to standards. In addition, one can learn about issues that affect engineering librarians professionally as well. The author has posted questions on the listservs and many times has received answers from fellow engineering and STEM librarians who are willing to help (See Subclaim 3.1). Listservs have proven to be one of the leading sources of information for finding out about conferences and other professional development opportunities.

Subclaim 2.3 Take advantage of learning about engineering through Twitter

Another way the author has learned about the engineering subject matter is through setting up a professional Twitter feed. As she liaises to both sciences and engineering, her Twitter feeds and posts reflect involvement in both fields. The author follows different engineering Twitter feeds, and by reading the daily posts of articles or re-tweets from others, she has gained a fair amount of knowledge about engineering. She liaises to civil, computer, mechanical, electrical, and general engineering and therefore follows Twitter feeds in each of these fields, most of which are based in the US or Europe. She also follows the feeds of the university of her employment and other universities in the United Arab Emirates, particularly those with science and engineering departments, keeping her up to date on all new research in the country of her residence. In addition, she follows the feeds of other engineering and/or STEM librarians who appear to update their professional twitter accounts. She has publicly announced her Twitter feed to all faculty in engineering and the sciences and has also added 
her Twitter username, @desertSciEnglib, to the signature line of her work email. The author only recently started a twitter account in September and if she had known how much knowledge would be gained from it, she would have started years earlier.

Claim 3. Network with other librarians and those in related fields

Embarking on a new liaison field can be daunting to a librarian, especially in the cases where the librarian does not possess a degree in the subject matter to which they liaise. It can be difficult to determine what a librarian should be accomplishing from the collection development standpoint, for example, and what the librarian should be paying attention to, with regards to patrons. Networking can prove to be helpful in solving these dilemmas. In a survey of science and engineering librarians who belong to professional library associations, attending the conferences of those associations to network with peers can often lead to answers to librarianship questions ${ }^{16,17}$. At the University of Toronto libraries, mentoring is viewed as an investment in the success of its librarians ${ }^{17}$. Although there is an abundance of literature on networking with faculty, there is little in the literature about networking with professionals who are not faculty. One exception is the argument for librarians to join professional associations of the areas they liaise to, which will significantly aid in collection development among other duties, in addition to raising the profile of the librarians among the faculty they liaise to ${ }^{18}$.

Subclaim 3.1 Network during business trips with experienced engineering librarians When the author assumed a liaison role to the engineering department, she was barely a year into the new role as a Science Librarian. Each of the librarians at NYUAD will visit the main campus in New York once a year, to meet with colleagues, attend meetings, and collaborate. The author decided to take advantage of the fact that she was visiting the US and meet up with engineering librarians at other universities, as at the time Tandon School of Engineering had not yet been incorporated into NYU. The author was scheduled to take part in a patent training (See Subclaim 3.2) in Boston after the New York campus visit. So before leaving New York, she arranged appointments with the Engineering Librarian at Columbia University and one of the engineering librarians at Massachusetts Institute of Technology. The author had set questions to ask them both and approached the meetings from the angle of an informational interview. These meetings were extremely helpful in that they provided insight on what kind of resources and services they provide as engineering librarians. This was also a much more authentic way to learn about the field than subscribing to listservs (See Subclaim 2.1). In the United Arab Emirates, as in the Arab World in general, it is customary to meet people in person as this strengthens ties much further than asking questions through email or phone. Perhaps it was the author's six years of experience working in the Gulf Cooperation Council countries that subconsciously motivated her to meet the librarians in person. Whatever the reason, the time and effort was well worth the increase in knowledge.

Subclaim 3.2 Networking may lead to training programs for your patrons While on the patent training course, the author found the section on patent law very intriguing and chatted with the instructor after the session. Upon discovering that the instructor would be coming to the UAE later that year for a conference, she asked if the instructor could conduct a session for the science and engineering community at NYUAD. Fortunately, she agreed to do more; in collaboration with another partner at her firm they conducted a Patent Research Lecture series, in which she and her colleague presented a different topic each day at lunchtime for four days, with regards to patents in the academic context. What added to the session was that both she and her colleague have degrees in science. Before choosing to enter the law field, she attained her graduate degrees in plant 
physiology and plant molecular biology and her colleague earned his graduate degree and postdoctoral work in chemistry. So the scientists and engineers who attended the session felt comfortable asking technical questions. The sessions were well attended, including all of the senior engineering students, who work on capstone projects that can potentially be patented. At this time, the university has had more than 20 patents filed over the past seven years of its existence, the overwhelming majority of which faculty are the inventors. Therefore this talk was definitely needed to inform and educate the NYUAD community as it takes on a path of continuing innovation. Although the speakers are not engineers by training, they spoke on a topic of great interest to the science and engineering community.

Claim 4. Alert yourself to information literacy needs of the engineering students.

As the Science and Engineering Librarian, the author noticed a difference in the way both scientists and engineers access information within their fields. Although the author could not pinpoint the exact difference, the literature proves that her observations are true. According to Chang and Eskridge, engineers generally do not make use of library resources and services and do not use the library ${ }^{19}$. If both the students and faculty are unaware of library resources, this gap in information literacy can negatively impact students once they graduate ${ }^{20}$. Blowers and Williams advocate for the need to combine information literacy skills with lifelong learning skills so that students are optimally primed not only for their university career but for life after school ${ }^{21}$.

In addition to information literacy, patent information literacy is also of importance at the university where the author is employed, as innovation is highly supported by the engineering department and the university. This is not an anomaly in the academic setting, and it is quite common that students learn how to search for patents. In fact, in an informal survey conducted in 2008 among engineering academic librarians, 58\% taught workshops on patent searching at least once a year ${ }^{22,23}$. Librarians at West Virginia University have partnered with faculty to create an Information Literacy program for first year engineering students that incorporates patent searching ${ }^{24}$. Internationally, searching for patents is also creeping into genetics and biotechnology information literacy programs at two Canadian universities ${ }^{25}$ and in China, $55 \%$ of academic libraries provide patent information services ${ }^{26}$.

Subclaim 4.1 Become literate in patent education to meet the demands of students and faculty NYUAD's engineering program for undergraduates encourages students to think differently about problems, because thinking differently fosters innovative solutions to problems. Innovation is such a key aspect of education that all first year students who intend to major in any of the engineering specialties, must enroll in a course called Design and Innovation. This is an intensive three-week class offered in the month of January, in which students learn about patents and innovation, and must create a unique invention that is presented at a special "open house" at the end of the class to the NYUAD community. In order to create a unique invention, students must check to see if an invention does not already exist for what they want to create. So the author teaches the students how to search the patent literature in the first week of class. The first time she began to do this in 2014, she was unable to answer many of the excellent questions asked by students because she did not posses the knowledge. There was a definite need to fill this knowledge gap. Following a trip to the New York campus (See Subclaim 3.1) the author participated in a Patent training provided by the Patent Information Users Group, PIUG in Boston the week after ${ }^{15}$. This was an excellent intensive two-day training course that explained patents from the legal, user, and information specialist perspective. After taking the course, the author was more confident about answering student questions the following year. The following year, 2015, she received questions from students 
who wanted to patent an invention. These questions made the author aware of another knowledge gap regarding the process of patenting an invention created by an NYUAD student. So in another trip to the New York campus the following year, she met with one of the directors of the Technology Transfer Office. This meeting was extremely useful in that the author learned not only the process involved for student inventors but for Staff/Faculty inventors as well and the Technology Transfer Office's role in the university.

Subclaim 4.2 Assess your involvement in Information literacy skill level of students As any academic librarian can attest, in an academic setting students will be a top priority. Therefore it is of utmost importance to pay attention to what skills they are lacking in the information literacy field. Many times, this will be ascertained upon talking with the faculty and teaching library skills in their classes (See Subclaim 1.1). Other times, it is up to the engineering librarian to become aware of what skills the students should be carrying with them once they graduate from the institution. After teaching one-shot instruction sessions to the engineering students for a year and a half, the author noticed that she would teach library instruction sessions to them three times in the first year, no times in the second or third year and one time in the senior year. There is obviously a large gap of two years where the students are not receiving library instruction sessions. She also noticed that when she surveyed the senior students, most of them had forgotten some of the basic database searching skills taught to them in year one. So the author has made it a goal to teach one session to the students in-class sometime during the second year, as they are all away for a study abroad during the junior year. Upon discussing this dilemma with the new dean, the dean mentioned this in a faculty meeting and fortunately the faculty agree that the students should be exposed to a library instruction session in year two. The author is currently working with faculty to determine which class is best to teach this instruction session and which skills should be taught.

\section{Future Directions}

The author has yet only begun her career as a Science and Engineering Librarian, as she has worked in this field for a little less than three years. She has begun to attend conferences in her liaison fields, and attending paper and poster presentations has piqued her interest for possible research projects. There are still many fields within librarianship and/or scholarly subjects that the author would love to research such as open access use, altmetrics and information literacy to name a few. The author has taken a course on research data management to understand the data needs of the science and engineering faculty, postdocs, and staff. Due to the author's location in the Middle East, she often participates in webinars of different subjects to facilitate her professional development. The author plans to continue to participate in engineering seminars and to find more ways to integrate into the engineering curriculum to become as embedded as possible. This will not only help the author develop professionally but will also possibly strengthen ties with the department and raise the profile of the author and the library she represents.

Although this has been the route for patenting an engineering librarian for my situation, this is by no means the endpoint. Just as a patent will undergo revisions and updates, so will this engineering librarian. I must constantly keep up with new changes in the Engineering program at my university and also with trends in the engineering field and engineering information literacy in order to fully provide the best service possible as an information professional. It is also critical to continue attending events held by the engineering department and continue to build upon the contacts I have within the program. Over time, a department and a field can change and it is up to the librarian to keep up with all the changes. 
A dynamic and open-minded information professional can prove to be crucial characteristics that will lead one to continually evolve as a successful engineering librarian.

[1] A. Magid, "The Road to Interactive Patent Searching at an American University in the UAE," presented at the IEEE Educon Global Engineering Education Conference, Abu Dhabi, United Arab Emirates, 2016.

[2] United States Patent and Trademark Office. (2015, January 31,). The Claims. Available: http://www.uspto.gov/web/offices/pac/mpep/s1824.html

[3] European Patent Office. $(2015,2016)$. What is prior art? Available: https://www.epo.org/learningevents/materials/inventors-handbook/novelty/prior-art.html

[4] G. Quinn. (2014, 2016). Understanding Patent Claims. Available: http://www.ipwatchdog.com/2014/07/12/understanding-patent-claims/id=50349/

[5] A. Magid, "The Road from Medical to Science-Engineering Librarianship," in Career Transitions for Librarians: How to Get Job in Another Library, R. Pun and D. E. Anderson, Eds., ed: Rowman and Littlefield Publishers, Inc., 2016.

[6] M. S. Nelson, "Marketing the Engineering Library," presented at the American Society of Engineering Education Annual Conference, Austin, Texas USA, 2009.

[7] S. J. Dooley, "Collaboration With Faculty: What They Don't Teach You In Library School," presented at the American Society of Engineering Education Annual Conference, Austin, Texas USA, 2009.

[8] S. Collard, I. Datig, and A. Magid, "Reference and Research Services in a Global Campus Environment," in Bridging Worlds: Emerging Models and Practices of U.S. Academic Libraries Around the Globe, R. Pun, S. Collard, and J. Parrott, Eds., ed Chicago: ACRL Publications, 2016.

[9] B. Trott and I. D. Silver, "Outreach Activities for Librarian Liaisons," Reference \& User Services Quarterly, vol. 54, pp. 8-14, Winter 2014.

[10] M. R. Tennant, "Customizing for Clients: Developing a Library Liaison Program from Need to Plan," Bulletin of the Medical Library Association, vol. 89 number 1, pp. 8-20, 2001.

[11] J. E. Pasek, "Organizing the liaison role," College \& Research Libraries News, vol. 76, pp. 202-205, 2015.

[12] Z. Y. Yang, "University faculty's perception of a library liaison program: a case study," The Journal of Academic Librarianship, vol. 26, pp. 124-128, 2000.

[13] M. Dalton, "'What Would I Tweet?": Exploring New Professionals' Attitudes Towards Twitter as a Tool for Professional Development," Journal of Library Innovation, vol. 4, pp. 101-110, 2013.

[14] J. Moreillon, "\#schoollibrarians Tweet for Professional Development: A Netnographic Case Study of \#txlchat," School Libraries Worldwide, vol. 21, pp. 127-137, 2015.

[15] A. Cullingford, "TWITTER : JOIN THE CONVERSATION," Bulletin of the Association of British Theological \& Philosophical Libraries, vol. 20, pp. 6-10, 2013.

[16] J. R. Davidson and C. A. Middleton, "Networking, networking, networking: The role of professional association memberships in mentoring and retention of science librarians," in Recruiting, Training, and Retention of Science and Technology Librarians, P. A. Kreitz and J. DeVries, Eds., ed New York: Taylor and Francis, 2013, pp. 203-224.

[17] A. Henshilwood, C. Sewerin, M. Spence, and T. Zahradnik, "Librarians: The next generation. Mentorship at the University of Toronto," presented at the American Society of Engineering Education Annual Conference, Seattle, Washington, 2015.

[18] M. H. Bennett, "The Benefits of Non-Library Professional Organization Membership for Liaison Librarians," The Journal of Academic Librarianship, vol. 37, pp. 46-53, 2011.

[19] P. C. Bertha and N. E. Honora, "What Engineers Want: Lessons Learned from Five Years of Studying Engineering Library Users," presented at the American Society of Engineering Education Annual Conference, Seattle, Washington, 2015.

[20] S. Purzer, M. Fosmire, A. S. Van Epps, R. E. H. Wertz, and K. A. Douglas, "Information Literacy Skill Development and Assessment in Engineering," presented at the American Society of Engineering Education Annual Conference, Indianapolis, Indiana, 2014.

[21] P. Blowers and B. Williams, "Deconstruction Of An Engineering Syllabus For Information Literacy," presented at the American Society for Engineering Education Annual Conference, Nashville, Tennessee, 2003. 
[22] M. J. White, "Patent Classification Reform: Implications for Teaching, Learning, and Using the Patent Literature," presented at the American Society for Engineering Education Annual Conference, San Antonio, Texas USA, 2012.

[23] M. J. White. (2008, January 27, 2016). How are Engineering Librarians Using Patent Literature? A Pilot Survey. Q Space at Queen's University. Available: http://hdl.handle.net/1974/1377

[24] M. L. Strife, R. A. M. Hensel, and M. G. Armour-Gemmen, "Integrating Information Literacy in Engineering: Librarians/Faculty," presented at the American Society of Engineering Education Annual Conference, San Antonio, Texas, 2012.

[25] D. MacMillan and M. Thuna, "Patents under the microscope: Teaching patent searching to graduate and undergraduate students in the life sciences," Reference Services Review, vol. 38, pp. 417-430, 2010 .

[26] J. Feng and N. Zhao, "A New Role of Chinese Academic Librarians-The Development of Embedded Patent Information Services at Nanjing Technology University Library, China," The Journal of Academic Librarianship, vol. 41, pp. 292-300, 2015. 